\title{
Multicriteria decision making with ELECTRE III, SOLAP and GIS for spatiotemporal tuberculosis analytics
}

\author{
Type of article: Conference abstract \\ Fatima-Zohra Younsi \\ LIO Laboratory, University of Oran 1, University of Abdel Hamid Ibn Badis, \\ Algeria \\ fatima.younsi@univ-mosta.dz
}

\begin{abstract}
Background: Epidemic spread is a major public health problem. Rapid detection of the agent, identification of factors promoting spread of epidemic and effective treatment are important parameters in controlling the disease.

The purpose of this research is to develop a novel epidemiological surveillance system based on Multi Criteria Analysis Method (MCAM) and Geographical Information System (GIS) technology integrated into a decision support system called SYstème Décisionnel Spatiotemporel pour l'EPidémiologie (SYDSEP). The later was designed, implemented and validated in previous research for tuberculosis risk assessment.
\end{abstract}

Methods: We highlight the use of ELimination and Choice Expressing REality III (ELECTRE III) ranking method of MCAM in GIS that incorporate environment, socio-economic, medical factors to monitor and identify potential high-risk areas of tuberculosis and disease mapping. Factors related to the risk of tuberculosis are obtained from SYDSEP and constitute the input values of ELECTRE III ranking method for the 26 communes of the city of Oran (Algeria).

Results: The outcomes from the combination of GIS and ELECTRE III produced useful information on different levels of risks. Thematic maps on incidence numbers of disease are created to classify the TB incidences from the highest level to the lowest level. Thus, we can easily obtain the major factors that influence the spread of disease and lead to increasing numbers of confirmed cases.

Conclusion: GIS based ELECTRE III method within SYDSEP has demonstrated analytical capabilities in targeting high-risk spots and TB surveillance monitoring system of the city of Oran and it can help public health policy makers prioritizing their response goals and evaluating control strategies.

Keywords: SYstème Décisionnel Spatiotemporel pour l'EPidémiologie (SYDSEP), Multicriteria analysis, ELECTRE III ranking method, Geographic Information System (GIS), Tuberculosis disease mapping.

\section{Declaration of conflicts}

This article is selected from the abstract's book of the International Conference on Health Sciences and Medical Technologies,10-12 October 2017, Tlemcen, Algeria, ICHSMT' 17.

\section{Authors' biography}

No biography 
Medical Technologies Journal, Volume: 1, Issue: 3, July -September 2017, Pages: 57-58. DOI: https://doi.org/10.26415/2572-004X-vol1iss3p57-58

\section{References}

1. Maystre, L. and Simos, J. P. J. (1994). Méthodes multicritères Electre. Edition Presses Polytechniques et Universitaires Romandes.

2. Gosselin, P., Lebel, G., Rivest, S., \& Douville-Fradet, M. (2005). The Integrated System for Public Health Monitoring of West Nile Virus (ISPHM-WNV): a real-time GIS for surveillance and decision-making. International Journal of Health Geographics, 4(1), 21.

3. Younsi, F. Z., Hamdadou, D., and Beldjilali, B. (2009). Proposition d'un Système Interactif d'Aide à la Décision Spatiale: Télédétection, SIG et Analyse Multicritère. In CIIA.

4. Younsi, F. Z. (2016). Mise en place d'un Système d'Information Décisionnel pour le Suivi et la Prévention des Epidémies (Doctoral dissertation, University of Oran 1 and Lyon 2). 